\title{
The Language Variety and the Meaning of Javanese Culture in the Event of Tantingan and Tebus Kembar Mayang in the Night of Midodareni
}

\author{
Hanif Magfiroh* Agus Subiyanto \\ Department of Linguistics, Faculity of Humanities, Diponegoro University, Semarang-Indonesia
}

\begin{abstract}
Javanese tribe has special acts in doing their sacred ceremony or ritual. One of their sacred ceremony is called midodareni belongs to the event of tantingan and tebus kembar mayang. The purpose of this study is to analyse the varied language used and its meaning related to the way of Javanese people through those two events. Therefore, this study is examined by using the theory of etnography communication. This study uses secondary data collected from Youtube. The result of the study shows that there are language variations in communicating to the interlocutor who has different role since Javanese people adhere to the communication pattern of unda usuk. The meaning of sub-event of tantingan is appropriate with Javanese culture of doing every single thing carefully so there is a speech act aimed at reconfirming. Then, in the sub-event of tantingan also describes the characteristic of Javanese tribe who love their daughters. The meaning of that sub-event of tebus kembar mayang is correlated to Javanese culture of hoping an everlasting marriage which is symbolized with kembar mayang, and every form kembar mayang not be separated from the nature, so it shows that Javanese people have a synergy with nature.
\end{abstract}

Keywords: Language variety, tantingan, tebus kembar mayang

\section{Introduction}

As one of tribes in Indonesia, Javanese tribe has such a rich traditional ceremonies, one of them is wedding ceremony. It consists of several sequences of events, yet this study only focuses on the ceremony of midodareni. Midodareni is an event carried out by Javanese people in a night right before their wedding. It is carried out in which the future bridegroom visits his future bride's house by bringing some seserahan or stuffs like clothes and jewelries. Clifford Geertz; cited from Susanti [1] described that Javanese people believe that midodareni ceremony is for getting salvation. Besides, they also believe that in that

* Corresponding author: hanif.magfiroh@gmail.com 
night a nymph will help them to beautify the bride and to bless the future bridegroom and the bride. Yet, in other hand, there is also who says that the word midodareni is from the word widada areni, or widada ari or ari kang widada which means "a fine day" (Mulyono, [2]).

In all sub-events of midodareni, there is a specific speech act that must exist. It has several language variations and contains several meanings related to the Javanese culture. Therefore, this study uses etnography communication theory to analyze language variations found in midodareni ceremony especially in the sub-event of tantingan and tebus kembar mayang, and to analyze its meaning implied related to the Javanese culture.

The Literature review used in this study are; the first is a study conducted by Salamah Eka Susanti [1] entitled Konsep Keselamatan Masyarakat Jawa Dalam Upacara Midodareni which infers that midodareni is the sort of tirakat or effort done by the bridge and the groom to get a salvation, in this case, everythings require in midodareni ceremony must be fulfilled and if there is one thing left, they will be not safe. The similarity of this current study with this previous study is about midodareni ceremony. Otherwise, this current study focuses on the language variations used in the speech act while this previous one focuses on its salvation concept.

The second literature review is a study carried out by Desi Lena Sari Butar-Butar (2019) [3] entitled Aktivitas Komunikasi Pra Prosesi Pernikahan Adat Batak Toba Sumatera Utara. It is found that there is a ritual in marhusip and martumpol prosession. The speech act occurred in several occasions; when the nephew asks for approval, when manulangi or spoon-feeding his uncle, and discussing mahar or bride price (Marhata Sinamot). This previous study is similar to this current study in the terms of examining pre-wedding prosession using ethnolinguisic approach. Otherwise, this current study focuses on Javanese traditions while the previous one focuses on Batak Toba tradition.

The third, a study on Pola Komunikasi Pada Prosesi Mangulosi dalam Pernikahan Budaya Adat Batak Toba carried out by Sirait and Hidayat (2015) [4]. The result of this previous study shows that the pattern of communication in the tradition is based on the communication situation, setting, message, and variation of the language itself, and there is a different act between the one who is getting married with or without using the tradition. This previous and current study is similar in the terms of examining the speech act in wedding tradition, yet, Sirait and Hidayah focuses on all communication patterns and its variations in the process of mangulosi in batak toba wedding tradition. Meanwhile, this current study only focuses on sub-event of tantingan and tebus kembar mayang in the midodareni of Javanese tradition.

The fourth is study conducted by Sugeha in (2017) [5] about Variasi Pilihan Bahasa Pada Masyarakat di Kabupaten Probolinggo: Kajian Etnografis which infers that there is a form of choosing languages like the variations of choosing code, the level of speech act, the variety of languages by dwibahasawan in Probolinggo regency. The implementation of language variety in every social realm is showed by switching and mixing the code. Both this current and previous study focuses on language varieties, but Sugeha uses ethnographic theory while the researcher uses ethnographic communication approach. Besides, the data source used by Sugeha is contextually based on communication of the society. Meanwhile the data source in this study is obtained from the communication happened in midodareni ceremony.

The last literature review a study carried out by Septiana (2012) [6] about Variasi dan Fungsi Bahasa dalam Riak pada Masyarakat Ma'Anyan (Kajian Etnografi Komunikasi). This previous study explains that there is differentiation between the language used daily and in riak ceremony, the variety like in the words, phrases, and expressions. Informative, interactive, and imaginative function occurs in the speech act of riak. The speech act of riak also has various meanings such as gathering, joking and showing identity. This current and 
previous study is similar in the terms of examining language varieties found in certain traditional ceremony by using ethnographic communication approach. Yet, this previous one is different with this current study in the terms of data collected; this current study uses the data of speech act of tantingan and tebus kembar mayang while the previous one is about speech act of riak.

In this study, the theory ued to analyse is the theory of sociolinguistic by using ethnographic communication approach. Both of them are actually focuses on observing the use of the language, but the sociolinguistic one more focuses on language variation and grammatical form while ethnographic communication approach more focuses on how communication units are organized and how the communication pattern is correlated each other and obtaining the meaning of every cultural aspect (Saville-Troike 2003) [7].

\section{Research Method}

This study is a descriptive qualitative study. The data used here is in the form of speech act found in midodareni ceremony especially in tantingan and tebus kembar mayang. Tutur tantingan is conducted by the bride and her father while tebus kembar mayang is done by a man who search kembar mayang and bride's father.

According to Sudaryanto 2015 [8], research method is used to collect or analyse the data, while the technique is defined as the way to implement the method. Non-participatory observation, interview, and literature review are the method of collecting data used in this study. Non-participatory observation is carried out since the researcher could not directly participate due to the the pandemic of Covid-19 from the beginning of Mei 2020. So, the researcher used Youtube (https://www.youtube.com/watch?v=HL s-XKHJOw\&t=1s) [9] to observe (secondary data). To get a valid data, the researcher also interviewed pranatacara (master of ceremony) as the expert who comprehends everyrules in midodareni ceremony. The technique used in non-participatory observation and interview is simak (listen), and catat (write). Furthermore, the researcher used literature review to collect all informations about midodaerni from some previous study. It used catat technique as the technique of collecting data.

The method of anaylizing data is carried out by using ethnographic communication approach. There are several steps in analysing the data; the first is the researcher looks for video about speech act of tantingan procession, and tebus kembar mayang in the night of midodareni as one of Javanese tradition. The second, the researcher listens to the spoken speech act. The third, the researcher writes all listened-materials into a transcript. The fourth, the researcher analyses language varieties found in tantingan and tebus kembar mayang procession as a part of midodareni.

\section{Discussion}

\subsection{Analysis Unit of Midodaerni procession}

Before analysing the language variety occurred in the speech act, it is needed to explain further about all analysis units. Analysis unit of ethnographic communication approach is divided into three; communication situation, communication event, and the act of communication or speech act (Hymes dalam Savile-Troike 2003) [7]. The followings are the analysis unit of communication pattern occurred in the night of midodareni procession of Javanese tradition; 


\subsubsection{Communication Situations}

Communication situation is the setting of speechs belongs to the context of situation. The communication situation occurred in the communication pattern of the night of midodareni is in the night and at the bride's house. Generally, the participants involved here are the bridegroom and the bride along with their parents, all their booth relatives, pranatacara (master of ceremony), and the unmarried male assigned to look for kembar mayang.

\subsubsection{Communication Events}

Based on the result of observing the video on Youtube and having interview with pranatacara (master of ceremony), all sub-events of midodareni is as follows:

\subsubsection{Jonggolan}

Jonggolan is a process which the bridegroom comes to the bride's house and he is given a water by the bride's mother since it is believed that the bridegroom have had a long journey. Afterwards, the bridegroom's family gives what it is called paningsed or seserahan or some stuff such as clothes, golds, fruits, or traditional snacks.

\subsubsection{Tantingan}

Tantingan is process when the bride is asked whether she is really sure or not to be married with the bridegroom. Besides, the bride asks her parents to look for kembar mayang for her.

\subsubsection{Tebus Kembar Mayang}

Tebus kembar mayang is a process of hadover of kembar mayang between a man who is assigned to look for kembar mayang and the bride's father.

\subsubsection{Sabda Tama Catur Wedha Recitation}

Sabda tama catur wedha is recited by the bride's father to the bridegroom. It contains four advices. Generally, the four advices are about the life as husband and wife. The first, the bridegroom and the bride must realize that the life after marriage is far different from the before one. The second, they have to respect their parents-in-law like they respect their own parents since the parents-in-law have already regarded them as their own children. The third is they have to obey the rules of the country and to love each other. The fourt is they have to uphold their religion. After that, sabda tama catur weda is given to the bridegroom to indicate that the bride's father already board out the responbility to him, and he already promised, as the future son-in-low, to obey those four advices after their marriage. 


\subsubsection{Speech acts in Tantingan and Tebus Kembar Mayang event}

\subsubsection{Speech acts in Tantingan}

The process of tantingan is carried out in the bride's bedroom in order to not be seen by the bridegroom. The participants involved here are the bride and her own parents. The followings are the verbal speech acts occurred during tantingan procession.

The bride's father

: Nduk.. Anakku sing tak tresnani, sesuk isuk dina Sabtu Kliwon tanggal 26 Juni tahun 2010 jam 08.00 isuk sliramu bakal tak daupke karo Mas Nur Farid. Sepisan maneh nduk, apa koe wes mantep tenan karo mas Farid?

(Dear my beloved daughter, tomorrow, Saturday kliwon $26^{\text {th }}$ June 2020 at $08.00 \mathrm{am}$, you will be getting married with Nur Farid. Once again, are you really sure to be married with Farid?)

The bride $\quad$ :Inggih bapak lan ibu, dalem sampun mantep, estu lan nyuwunipun daupaken kalian kang mas Farid. Nanging kula nyuwun dipadosaken dolanan kembar mayang nggih. (Yes I am dad, and mom, I am really sure to be married with Farid. But, I request for kembar mayang)

The bride's father : iya, ya nduk.. Wis dadi kewajibane bapak ibumu opo panyuwunmu bakal tak laksanakke. Ayo nyuwun marang Gusti, muga-muga panyuwunmu keparingan dalan ingkang gampang nggih nduk..

(Well, okay dear, it is our responsibility to fulfil your request. Let's pray to God, hope what you want will be easy to fulfil)

\subsubsection{Speech acts in Tebus Kembar Mayang}

Tebus kembar mayang is the process of handover kembar mayang between A man who looks for kembar mayang and the bride's father. There are two speech acts here, verbal and non-verbal. The following is the verbal speech act in tebus kembar mayang.

Dendi Satrio Utama

: Nuwun, kula Dendi Satrio Utama ingkang kautus mboyong kembar mayang sampun angsal damel. Awit saking menika kula pasarahaken dumateng bopo Sri Mulyana sekalian kagem daupipun mbak Anti kalian Mas Farid. Mugi-mugi Gusti ingkang Maha Agung paring berkah pangayoman kawilujengan tebih saking punapapunapa, saha widodo ing sambikala. Nuwun maturnuwun. (Excuse me, I am Deni Satio Utama who request to bring kembar mayang have been done. Therefore, I hand it out to you, Mr. Sri Mulyana, it is for Anti and Farid wedding. May the almighty God give them his protection and keep them away from any obstacles, thank you).

The bride's father :Kula ngaturake maturnuwun awit jenengan sakrombongan sampun saged mboyong kembar mayang kangge daupipun anak kula Anti kalian Mas Farid. Kula sakeluarga ngaturake panuwun, mugi-mugi Gusti Allah paring 
ganjaran marang panjenengan, ing saklajengipun anak kula saged dadi kaluarga sakinah mawadah warahmah ngabekti dumateng tiyang sepuh lan saged nindakaken ajaran agami.

(Thanks to you and the entourage for bringing kembar mayang for my daugther's wedding, Anti, with Farid. My family and I want to say thank you, may Allah reply of what you all done, hope my daughter can have a sakinah, mawaddah, and warrohmah family, serving and devoting to their parents, and can do all their religion's obligation).

\subsection{Language Variety in Tantingan and Tebus Kembar Mayang}

According to Saville-Troik (2003) [7] The use of language variety in socio-cultural is correlated to the setting, the realm of activity, region, ethnic, social classes, and role, role relationship; gender, age, personality and abnormal speech, not native speaker. In the case of the night of midodareni especially the speech acts in tantingan and tebus kembar mayang occurrs a language variety based on the role relationship or the variety caused by it. Saville-Troike (2003) [7] explained that the language variety caused by the role relationship is the phenomenon of the same speaker using different forms of language when talking to someone who has a higher social status compared to those who have a lower social status in the same conversation.

The appearance of language variety of the speech act in tantingan and tebus kembar mayang is not without a reason, because Javanese language implemented unda usuk system or language levelling. The variety in Javanese language is determined into two, krama and ngoko.

\subsubsection{Language Variety in Tantingan}

In tantingan, there are two Javanese language varieties occur; ngoko alus and krama inggil. Ngoko lugu is used by the bride's father and it is indicated with the use of lexicon of ngoko lugu, for instance, the lexicon koe which means "you". Meanwhile, krama lugu is used by the bride and it is indicated with the use of lexicon dipadosaken which means "sought by or to be looked for".

Those language varieties appear due to the existence of different role relationship. The bride has a role as a daughter who has to respect her parents so she used krama to communicate with her parents. Otherwise, the bride's father has a role as the parents and has a right to choose either ngoko or ngoko. The bride's father used ngoko alus to appreciate the bride.

\subsubsection{Language Variety in Tebus Kembar Mayang}

In tebus kembar mayang, the speech act is done by Dendi Satrio Utama as the one who responsibles to bring kembar mayang and the bride'father. There are two language varities appear, krama alus used by Dendi Satrio Utama and krama lugu used by the bride's father. Dendi Satrio Utama used krama alus since he has lower social status than the bride's father. Otherwise, since the bride's father has higher social status, krama lugu is used to show a politeness towards Dendi Satro Utama who gave his hand to look for kembar mayang. 


\subsubsection{Lexicon Variety in Tantingan and Tebus Kembar Mayang}

In the night of midodareni, there is a specific lexicon; kembar mayang. The lexicon of kembar mayang could not be found in daily conversation. Based on its forming elements, it is divided into kembar means pair or couple (two), and mayang means flower (pinang or betel). The name of kembar mayang is kalpataru. Kalpa means everlasting and taru means plants (Mulyono, 2002) [2].So, kembar mayang is a pair of betel flower as the symbol two people who have the same vision and mission and a new everlasting life. The symbol of new life in kembar mayang can be found in its forming components and content, which is mostly from the nature; leafs, flower, even fruits. This is indicated that the Javanese people are close to the nature, every aspects of their life are related to the nature.

Besides, the lexicon of kembar mayang asked by the bride to her father in tantingan is as symbol. Meanwhile, for a man who's looking for kembar mayang is as the real object. So, Javanese people really present a symbol for their attainment.

\subsection{The Meaning of sub-event Tantingan and Tebus Kembar Mayang based on Javanese Culture}

The meaning of sub-event tantingan based on Javanese culture is doing every single thing carefully and loving their daughters. The carefulness of doing every single thing is indicated by the speech act of reconfirming the wedding that will be carried out. The bride's father, as wali or the one who responsibles for his daughter marriage, asking the bride whether she is really sure or not, to avoid any regrets since the father's responsibility will be taken by his son-in-law. The love of parents to their daughter is indicated by actualizing their daughter request even it is difficult to do like looking for kembar mayang.

The meaning of tebus kembar mayang is representing Javanese culture which is hoping the everlasting marriage and it is symbolized with kembar mayang. Kembar mayang which is attached to the nature and it shows that Javanese people have a synergy with the nature, so every form of their actions could not be separated from the nature.

\section{Conclusion}

Based on the result of data analysis, it can be inferred that the speech act done by the future bride and her father, and a man who looks for kembar mayang is varied. The language variety is due to Javanese people adheres to unda usuk communication pattern or levelling in speech act because of different role they have. Besides, it is also found lexical variety, kembar mayang, in the night of midodareni.

The meaning of sub-event tantingan is appropriate with Javanese culture, do every single thing carefully by reconfirming to the authorized-one before doing it. Besides, Selain in the sub-event tantingan described the characteristic of Javanese people who loves their daughters. For the meaning of sub-event tebus kembar mayang is Javanese people is keen on everlasting marriage which is symbolized by using some biodiversities. Therefore, it can be indicated that everything is symbolized and Javanese people has such a good harmony towards the nature. 


\section{References}

1. S. E. Susanti, K.K.M.J.D.U.M. 5, 97-105 (2019)

2. D. Mulyono, Mutiara Dibalik Tata Cara Pengantin Jawa (2002)

3. D. L. S. N Butar-Butar, A.K.P.P.P.A.B.T.S.U. 1, 27-33 (2019)

4. D. M. Sirait, D. Hidayat, P.K.P.P.M.d.P.B.A.T. 2, 23-31(2015)

5. A. Z. Sugeha, V.P.B.P.M.D.K.P. 1, 125-144 (2017)

6. D. Septiana, Variasi dan Fungsi Bahasa dalam Riak pada Masyarakat Ma'Anyan (Kajian Etnografi Komunikasi) in Tesis University of Diponegoro (2012)

7. M. Saville-Troike, The Ethnography of Communication: An Introduction (2003)

8. Sudaryanto, Metode dan Teknik Analisis Bahasa (2015)

9. K. Ketawang, Proses Midodareni Pernikahan Adat Jawa in Youtube https://www.youtube.com/watch?v=HL s-XKHJOw\&t=1s (2016) 